\author{
K. Rokosz ${ }^{1 *}$, T. Hryniewicz ${ }^{1}$ L. Dudek ${ }^{1}$,W. Malorny ${ }^{2 *}$ \\ ${ }^{1}$ Koszalin University of Technology, Faculty of Mechanical Engineering, Racławicka 15-17 \\ 75-620 Koszalin, Poland \\ ${ }^{2}$ Hochschule Wismar-University of Applied Sciences Technology, Business and Design, \\ Faculty of Engineering, DE 23966 Wismar, Germany \\ rokosz@tu.koszalin.pl, ${ }^{2 *}$ winfried.malorny@hs-wismar.de
}

\title{
SEM AND EDS ANALYSIS OF NITINOL SURFACES TREATED BY PLASMA ELECTROLYTIC OXIDATION
}

\begin{abstract}
In the paper, the surface layers formed on nickel-titanium alloy during Plasma Electrolytic Oxidation (PEO), known also as Micro Arc Oxidation (MAO), are described. The mixture of phosphoric acid and copper nitrate as the electrolyte for all plasma electrochemical processes was used. Nitinol biomaterial was used for the studies. All the experiments were performed under the voltage of $450 \mathrm{~V}$ and current density of $0.3 \mathrm{~A} / \mathrm{dm}^{2}$. The main purpose of the studies was to achieve the highest amount of copper in the surface layer versus amount of the copper nitrate in phosphoric acid. The highest copper concentration was found in the surface layer after the PEO treatment in the electrolyte consisting of $150 \mathrm{~g} \mathrm{Cu}\left(\mathrm{NO}_{3}\right)_{2}$ in $0.5 \mathrm{dm}^{3} \mathrm{H}_{3} \mathrm{PO}_{4}$. The worst results, in case of the amount of copper in the NiTi surface layer, were recorded after oxidizing in the solution with $5 \mathrm{~g} \mathrm{Cu}\left(\mathrm{NO}_{3}\right)_{2}$.
\end{abstract}

Keywords: Plasma Electrolytic Oxidation; PEO; Micro Arc Oxidation; MAO; SEM; Titanium alloy; NiTi

\section{INTRODUCTION}

Nickel-Titanium alloy, also known as Nitinol, after a plasma electrolytic oxidation (micro arc oxidation) can be used in medicine as a biomaterial because of its very good biocompatibility. The other electrochemical treatments such as a standard electropolishing [1-3] as well as magnetoelectropolishing [3-7] can change the chemical composition of passive layers formed after those electrochemical treatments, improve their corrosion resistance, roughness and shine [1-7], but they do not form any porous layer; that layer is formed and visible after the plasma electrolytic oxidation (PEO) [8-11]. In the paper, the Authors present the SEM and EDS analysis of the porous layers formed after the PEO at $450 \mathrm{~V}$ for 3 minutes in the electrolyte consisting of $\mathrm{Cu}\left(\mathrm{NO}_{3}\right)_{2}$ and $\mathrm{H}_{3} \mathrm{PO}_{4}$.

Plasma electrolytic oxidation (PEO) is a surface finishing technique applied to obtain a range of hard and dense oxide coatings, produced on a variety of metals, such as aluminium, magnesium, titanium and other lightweight alloy substrates [8-13]. Most of the reported PEO techniques applies an alternative voltage of 220-300 V to reach the goal. The up-to-date publications indicate that a suitable control of electrolyte and the process conditions can realise 
a novel range of coatings having technologically attractive physical and chemical properties [13]. One of the recent papers underlines that the reducing of the osseointegration time for biomedical titanium implants in surgical patients is an important goal [14]. The aim of this work is to show the preliminary results of the PEO treatment performed on Nitinol.

\section{METHOD AND EXPERIMENTAL SET UP}

The experiment of the Plasma Electrolytic Oxidation (PEO) was carried out on a set-up (Fig. 1) built in a cooperation with the Division of Applied Electronics and Electrotechnology, Koszalin University of Technology (KUT). The PEO process was performed with the use of a constant voltage of $450 \mathrm{~V}$. The electrolyte solution consisted of $500 \mathrm{ml}$ of a concentrated $85 \%$ pure p.a. $\mathrm{H}_{3} \mathrm{PO}_{4}(98 \mathrm{~g} / \mathrm{mol})$ acid and dissolved therein 5 up to $300 \mathrm{~g}$ of $\mathrm{Cu}\left(\mathrm{NO}_{3}\right)_{2}$ with some amount of casually dissolved iron ions. The nickel-titanium samples of dimensions $100 \times 20 \times 5$ $\mathrm{mm}$, were prepared at the Faculty of Mechanical Engineering, KUT.

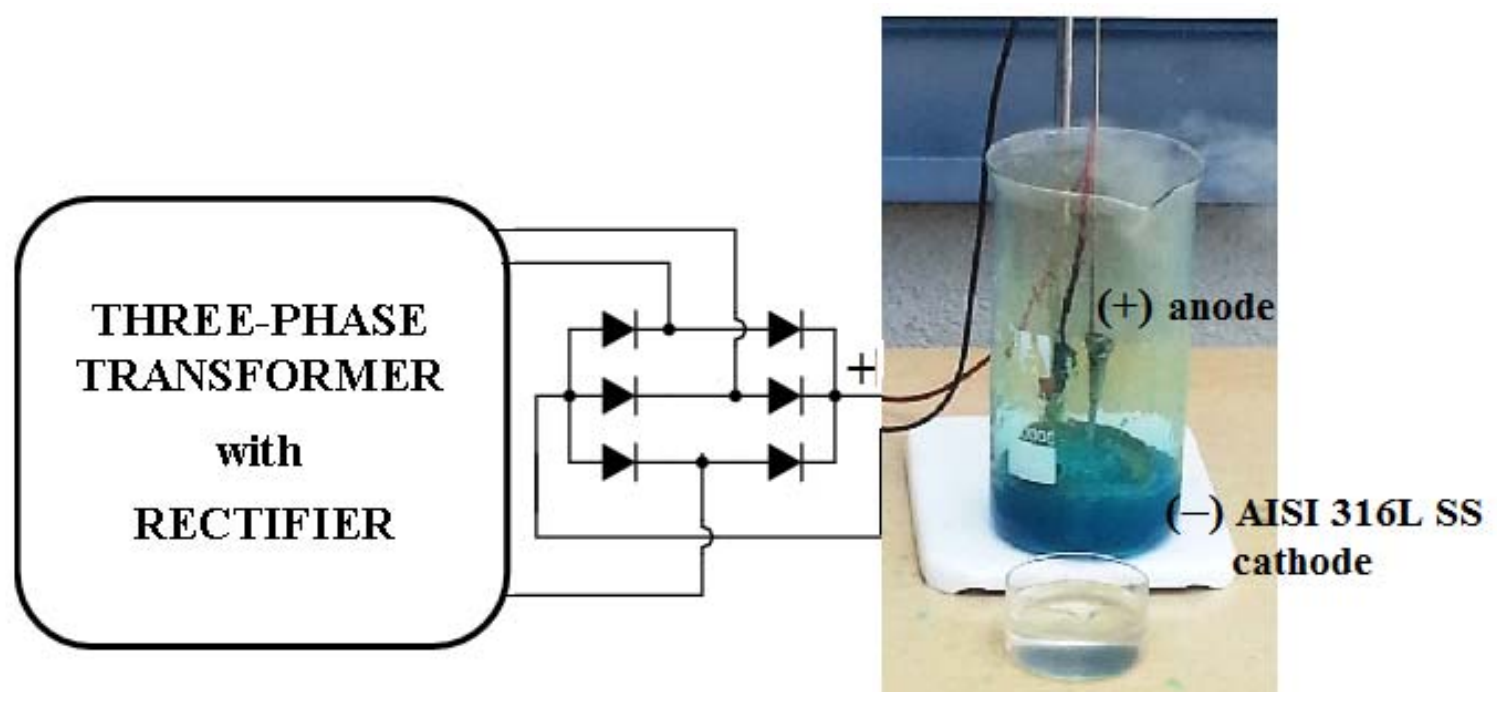

Fig. 1. Scheme of the set-up used for the PEO studies

\section{RESULTS}

In Figure 2, there is shown the SEM picture of NiTi alloy sample after the PEO treatment at $450 \mathrm{~V}$ for 3 minutes in the electrolyte consisting of $5 \mathrm{~g} \mathrm{Cu}\left(\mathrm{NO}_{3}\right)_{2}$ in $500 \mathrm{ml} \mathrm{H}_{3} \mathrm{PO}_{4}$. The obtained surface is not porous and consists mainly of nickel (35.3 wt \%) and titanium $(28.4 \mathrm{wt} \%)$ bonded with oxygen $(35.1 \mathrm{wt} \%)$ with the small amounts of phosphorus $(0.6 \mathrm{wt} \%)$ and copper $(0.6 \mathrm{wt} \%)$ (Fig. 3 and Table 1). This can be explained by the possibility of the surface layer creation in the concentrated phosphoric acid with a dissolved salt therein only, which in this case is the copper nitrate. A better situation is observed after the dissolution of $150 \mathrm{~g}$ of copper nitrate in $500 \mathrm{ml}$ of phosphoric acid. After the PEO treatment in that electrolyte there are visible pores (Fig. 4), which surely make the surface more biocompatible. Inside the surface 
layer the higher amount of phosphorus $(19.7 \mathrm{wt} \%)$ and copper $(3.7 \mathrm{wt} \%)$ were detected, that are depicted in Fig. 5 and Table 2. It should also be admitted that the amount of carcinogenic nickel is much less $(12.3 \mathrm{wt} \%)$ than that one noted after oxidizing $(35.3 \mathrm{wt} \%)$ in the electrolyte with a minimum $\left(5 \mathrm{~g} \mathrm{Cu}\left(\mathrm{NO}_{3}\right)_{2}\right)$ amount of copper nitrate in the half liter of phosphoric acid.

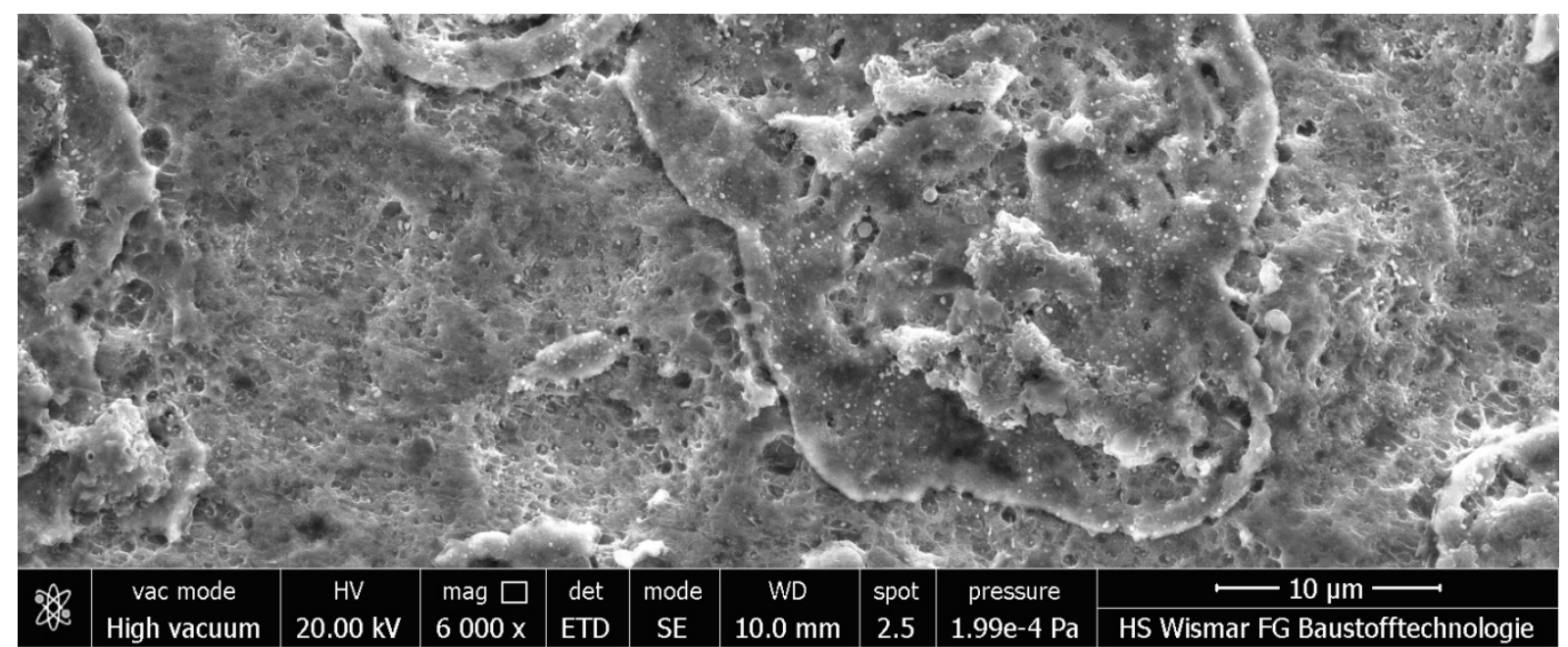

Fig. 2. SEM image of NiTi after PEO treatment at $450 \mathrm{~V}$ for 3 minutes in the electrolyte consisting of $5 \mathrm{~g} \mathrm{Cu}(\mathrm{NO} 3) 2$ in $500 \mathrm{ml} \mathrm{H} 3 \mathrm{PO} 4$

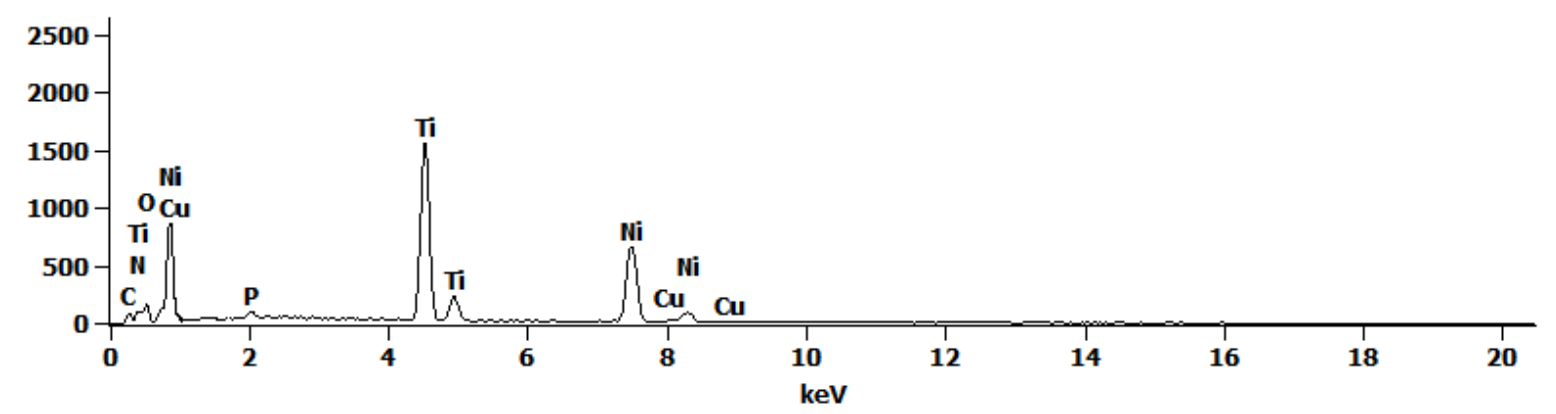

Fig. 3. EDS of NiTi after PEO treatment at $450 \mathrm{~V}$ for 3 minutes in the electrolyte consisting of $5 \mathrm{~g} \mathrm{Cu}(\mathrm{NO} 3) 2$ in $500 \mathrm{ml} \mathrm{H} 3 \mathrm{PO} 4$

Table 1. Chemical composition of PEO layer formed on NiTi treated at $450 \mathrm{~V}$ for 3 minutes in the electrolyte con-

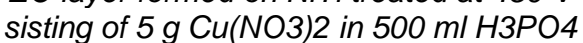

\begin{tabular}{|c|c|c|c|c|}
\hline Elements & $w t \%$ & $\begin{array}{c}\text { wt\% } \\
\text { ERROR }\end{array}$ & at\% & $\begin{array}{c}\text { at\% } \\
\text { ERROR }\end{array}$ \\
\hline$O K$ & 35.1 & --- & 64.2 & \pm 7.28 \\
\hline$P K$ & 0.6 & \pm 0.04 & 0.6 & \pm 0.07 \\
\hline TiK & 28.4 & \pm 0.21 & 17.3 & \pm 0.25 \\
\hline Ni K & 35.3 & \pm 0.61 & 17.6 & \pm 0.59 \\
\hline Cu K & 0.6 & \pm 0.21 & 0.3 & \pm 0.18 \\
\hline
\end{tabular}




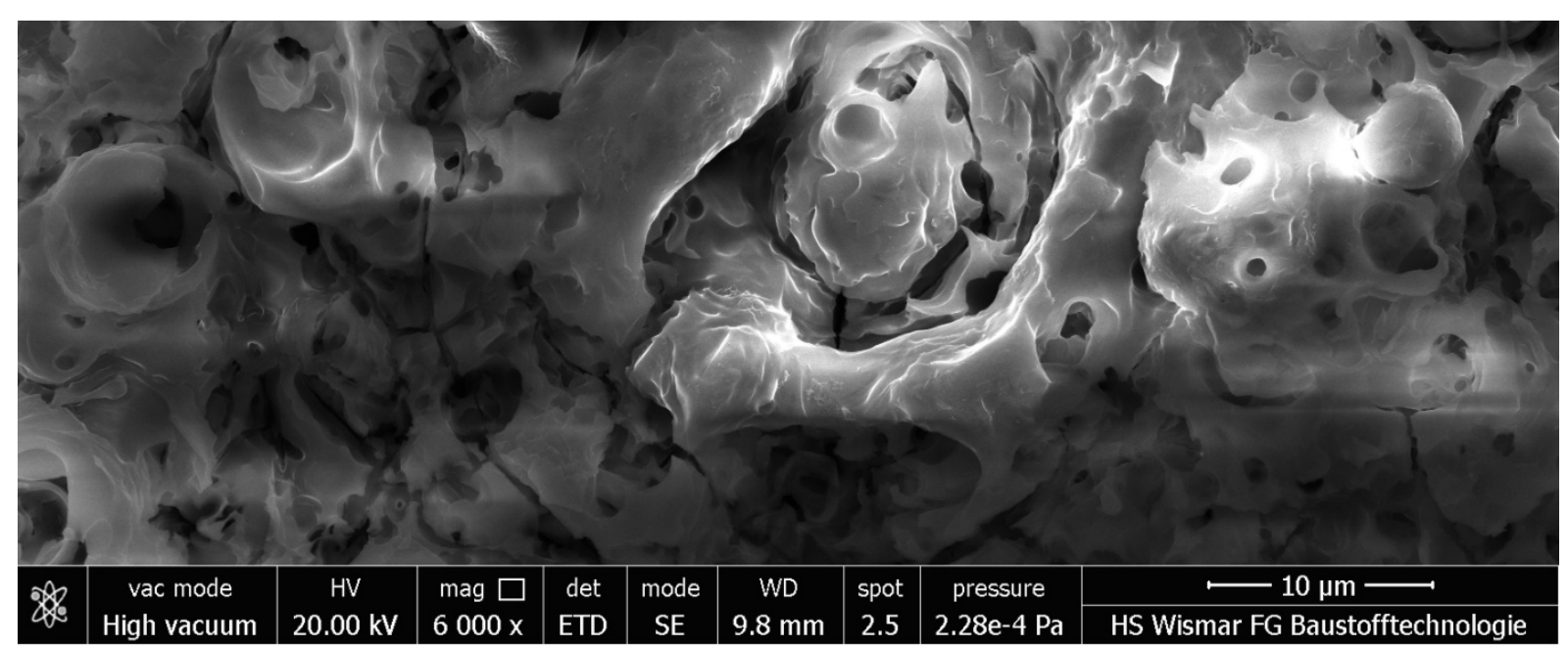

Fig. 4. SEM image of NiTi surface after PEO treatment at $450 \mathrm{~V}$ for 3 minutes in the electrolyte consisting of $150 \mathrm{~g} \mathrm{Cu}(\mathrm{NO} 3) 2$ in $500 \mathrm{ml} \mathrm{H} 3 \mathrm{PO} 4$

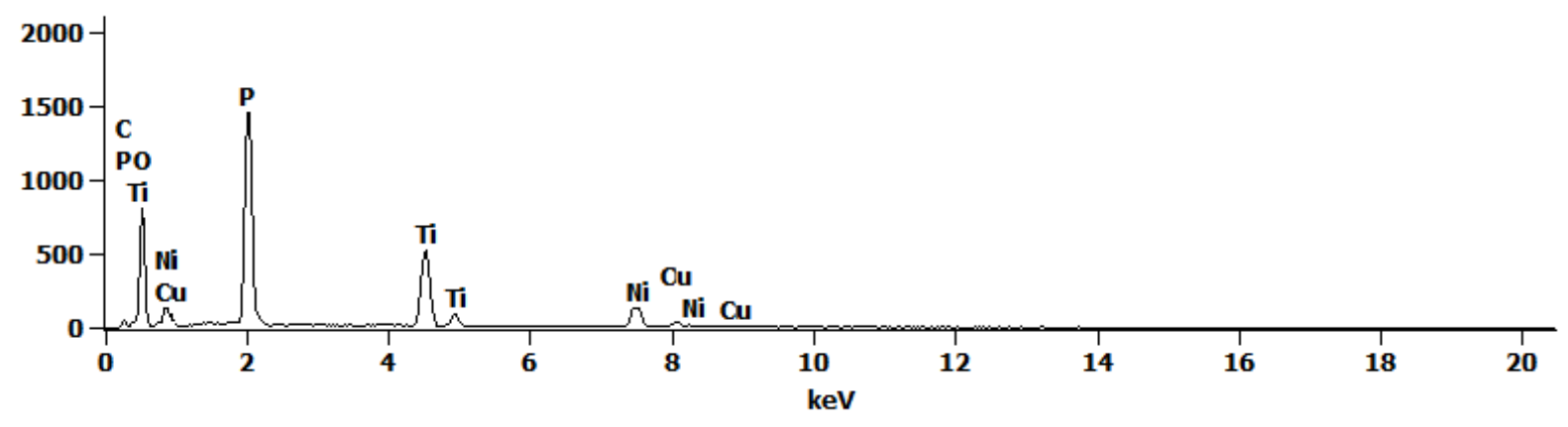

Fig. 5. EDS of NiTi surface after PEO treatment at $450 \mathrm{~V}$ for 3 minutes in the electrolyte consisting of $150 \mathrm{~g} \mathrm{Cu}(\mathrm{NO} 3) 2$ in $500 \mathrm{ml} \mathrm{H3PO} 4$

Table 2. Chemical composition of PEO layer formed on NiTi treated at $450 \mathrm{~V}$ for 3 minutes in the electrolyte consisting of $150 \mathrm{~g} \mathrm{Cu}(\mathrm{NO} 3) 2$ in $500 \mathrm{ml} \mathrm{H3PO4}$

\begin{tabular}{|c|c|c|c|c|}
\hline Elements & $w t \%$ & $\begin{array}{c}w t \% \\
\text { ERROR }\end{array}$ & at\% & $\begin{array}{c}\text { at\% } \\
\text { ERROR }\end{array}$ \\
\hline$O K$ & 46.9 & --- & 69.8 & \pm 2.02 \\
\hline$P K$ & 19.7 & \pm 0.22 & 15.1 & \pm 0.33 \\
\hline Ti K & 17.4 & \pm 0.21 & 8.7 & \pm 0.21 \\
\hline Ni K & 12.3 & \pm 0.58 & 5 & \pm 0.47 \\
\hline Cu K & 3.7 & \pm 0.34 & 1.4 & \pm 0.25 \\
\hline
\end{tabular}

In Figure 6, there is shown the SEM picture of NiTi alloy sample after the PEO treatment at $450 \mathrm{~V}$ for 3 minutes in the electrolyte consisting of $300 \mathrm{~g} \mathrm{Cu}\left(\mathrm{NO}_{3}\right)_{2}$ in $500 \mathrm{ml} \mathrm{H}_{3} \mathrm{PO}_{4}$. The high porosity with minimum of two pore levels are visualized. The chemical composition of the obtained layer is very similar to the second one, which was oxidized in the electrolyte with $150 \mathrm{~g}$ of copper nitrate. The EDS results shown in Fig. 5 and Table 2, indicate that copper $(3.7 \pm 0.34 \mathrm{wt} \%)$ and phosphorus $(19.7 \pm 0.22 \mathrm{wt} \%)$ amounts are very close to those ones presented in Figure 7 and Table $3(3.3 \pm 0.3 \mathrm{wt} \%$ of copper; $19.01 \pm 0.21 \mathrm{wt} \%$ of phosphorus). 
In this paper there are shown the preliminary studies of single measurements which do not allow to reveal the significant differences between the obtained results. For this reason the additional studies with a minimum of five repetitions are planned in the future, in order to carry out the tests of significance.

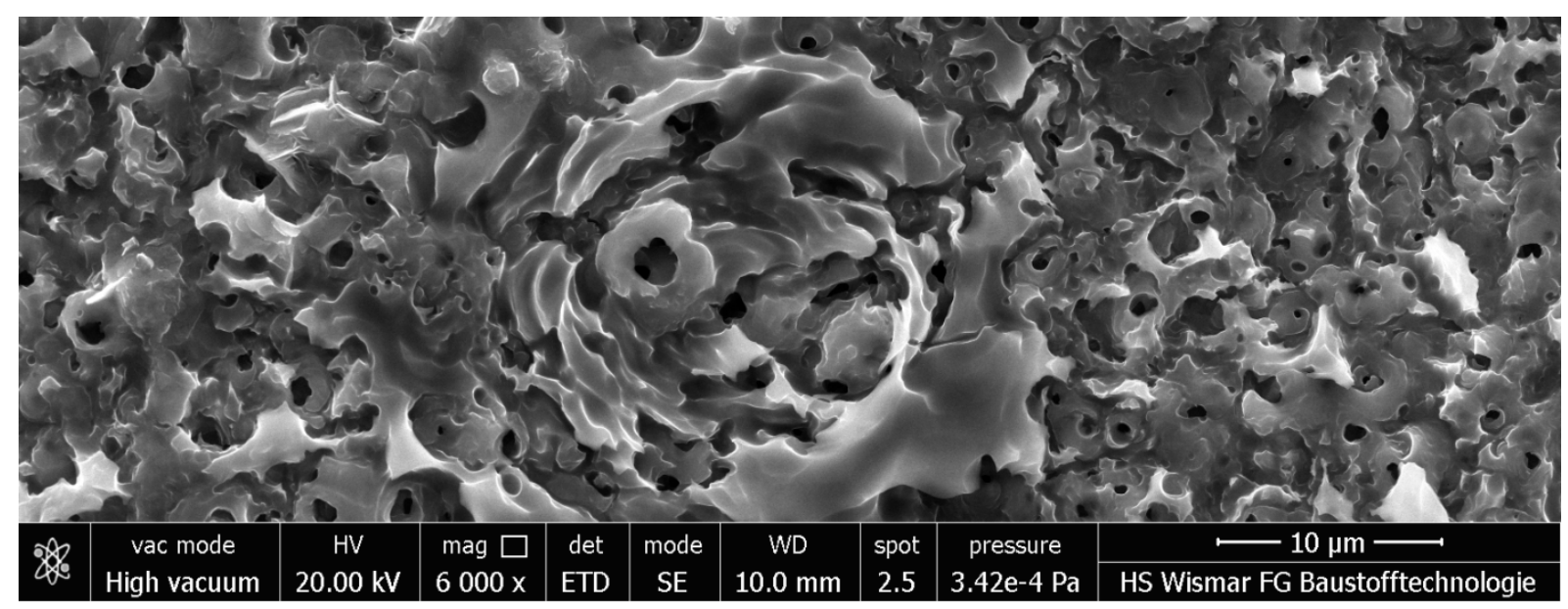

Fig. 6. SEM image of NiTi surface after PEO treatment at $450 \mathrm{~V}$ for 3 minutes in the electrolyte consisting of $300 \mathrm{~g} \mathrm{Cu}(\mathrm{NO} 3) 2$ in $500 \mathrm{ml} \mathrm{H} 3 \mathrm{PO} 4$

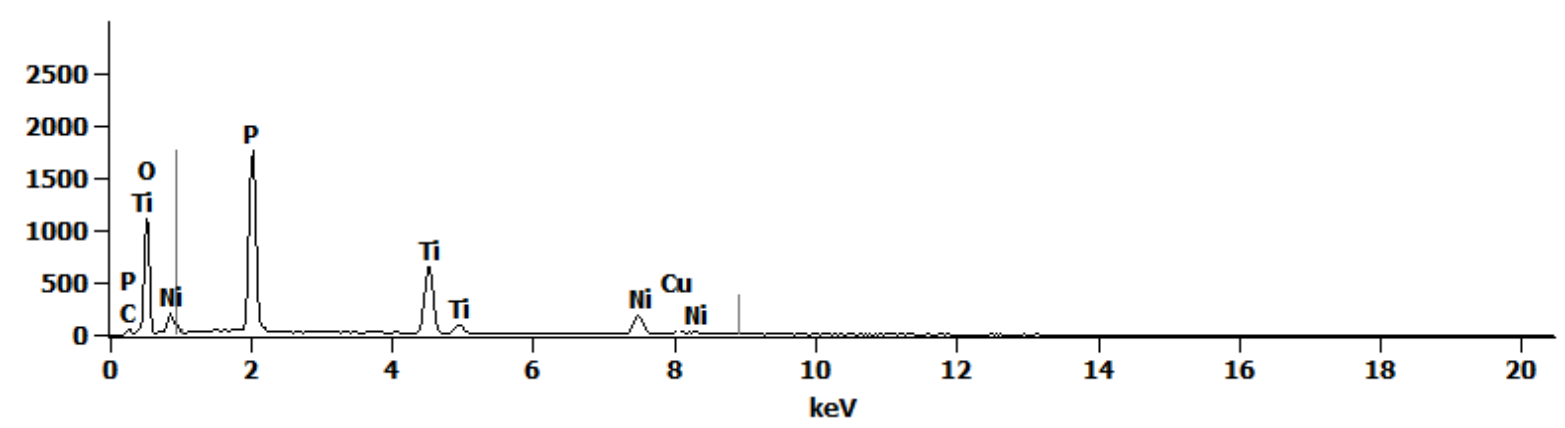

Fig. 7. EDS of NiTi surface after PEO treatment at $450 \mathrm{~V}$ for 3 minutes in the electrolyte consisting of $300 \mathrm{~g} \mathrm{Cu}(\mathrm{NO} 3) 2 \mathrm{in} 500 \mathrm{ml} \mathrm{H} 3 \mathrm{PO} 4$

Table 3. Chemical composition of PEO layer formed on NiTi treated at $450 \mathrm{~V}$ for 3 minutes in the electrolyte consisting of $300 \mathrm{~g} \mathrm{Cu}(\mathrm{NO} 3) 2$ in $500 \mathrm{ml} \mathrm{H} 3 \mathrm{PO} 4$

\begin{tabular}{|c|c|ccc}
$\mid$ Elements & wt\% & $\begin{array}{c}\text { wt\% } \\
\text { ERROR }\end{array}$ & at\% & $\begin{array}{c}\text { at\% } \\
\text { ERROR }\end{array}$ \\
\hline O K & 46.2 & --- & 69.5 & \pm 1.99 \\
P $K$ & 19.1 & \pm 0.21 & 14.8 & \pm 0.32 \\
Ti $K$ & 17.6 & \pm 0.27 & 8.8 & \pm 0.26 \\
Ni $K$ & 13.8 & \pm 0.55 & 5.7 & \pm 0.44 \\
Cu $K$ & 3.3 & \pm 0.30 & 1.2 & \pm 0.22 \\
\hline
\end{tabular}




\section{CONCLUSIONS}

In that paper, the results of the surface layers formed on the nickel-titanium alloy after the Plasma Electrolytic Oxidation (PEO), known also as a Micro Arc Oxidation (MAO), in the electrolyte consisting of phosphoric acid and copper nitrate, are presented. The main problem to solve was to put/insert copper ions inside the POE layer, and this task has been successfully done. The biggest amount of copper in the surface layer was recorded after the PEO treatment in the electrolytes consisting of $150 \mathrm{~g}$ and $300 \mathrm{~g}$ of copper nitrate in $500 \mathrm{ml}$ of phosphoric acid and it was equal over 3 weight percent. Trace amounts of copper $(0.6 \pm 0.21 \mathrm{wt} \%)$ and phosphorus $(0.6 \pm 0.04 \mathrm{wt} \%)$ after the treatment in the electrolyte with $5 \mathrm{~g} \mathrm{Cu}\left(\mathrm{NO}_{3}\right)_{2}$, were found. Following these results it can be concluded that in the absence of copper nitrate the surface layer consists mainly of nickel-titanium with some inclusions of copper phosphates and alloying elements. It should be also noted that the layers with the least amount of carcinogenic nickel (below $13 \mathrm{wt} \%$ ) are formed with a large amount of copper nitrate in the electrolyte.

\section{REFERENCES}

1. Hryniewicz T., Fizykochemiczne i technologiczne podstawy procesu elektrochemicznego polerowania stali (Physicochemical and technological bases of electrochemical polishing of steels), Monograph Nr 26, Publisher: Koszalin University of Technology, Koszalin 1989.

2. Hryniewicz T., Concept of microsmoothing in electropolishing process, Surface and Coatings Technology, 1994, 64(2), 75-80.

3. Rokosz K., Polerowanie elektrochemiczne stali w polu magnetycznym (Electrochemical polishing of steels in the magnetic field), Monograph Nr 219, Publisher: Koszalin University of Technology, Koszalin 2012, ISSN 0239-7129, (211 pages, in Polish).

4. Hryniewicz T., Rokosz K., Rokicki R., Electrochemical and XPS Studies of AISI 316L Stainless Steel after Electropolishing in a Magnetic Field, Corrosion Science, 2008, 50(9), 2676-2681.

5. Rokosz K., Hryniewicz T., XPS measurements of LDX 2101 duplex steel surface after magnetoelectropolishing, International Journal of Materials Research, 2013, 104(12), 1-10.

6. Rokosz K., Hryniewicz T., Raaen S., $\mathrm{Cr} / \mathrm{Fe}$ ratio by XPS spectra of magnetoelectro-polished AISI 316L SS fitted by Gaussian-Lorentzian shape lines, Technical Gazette, 2014, 21(3), 533-538.

7. Hryniewicz T., Rokicki R., Rokosz K., Magnetoelectropolishing for metal surface modification, Transactions of the Institute of Metal Finishing, 2007, 85(6), 325-332.

8. Simka W., Sadowski A., Warczak M., Iwaniak A., Dercz G., Michalska J., Maciej A., Modification of titanium oxide layer by calcium and phosphorus, Electrochemical Acta, 2011, 56(24) 8962-8968.

9. Simka W., Sowa M., Socha R.P., Maciej A., Michalska J., Anodic oxidation of zirconium in silicate solutions, Electrochemical Acta, 2013, 104, 518-525.

10. Simka W., Nawrat G., Chlode J., Maciej A., Winiarski A., Szade J., Radwanski K., Gazdowicz J., Electropolishing and anodic passivation of Ti6A17Nb alloy, Przemysł Chemiczny, 2011, 90(1), 84-90.

11. Jin F. Y., Tong H. H., Shen L. R., Wang K., Chu P. K., Micro-structural and Dielectric Properties of Porous $\mathrm{TiO}_{2}$ Films Synthesized on Titanium Alloys by Micro-Arc Discharge Oxidization, Materials Chemistry and Physics, 2006, 100(1), 31-33. 
12. Walsh F.C., Low C.T.J., Wood R.J.K., Stevens K.T., Archer J., Poeton A.R., Ryder Y. Plasma electrolytic oxidation (PEO) for production of anodised coatings on lightweight metal (Al, Mg, Ti) alloys, Transactions of the IMF, 2009, 87(3), 122-135.

13. Yerokhin A.L., Nie X., Leyland A., Matthews A. Characterisation of oxide films produced by plasma electrolytic oxidation of a Ti-6Al-4V alloy, Surf Coat. Technol., 2000, 130(2-3), 195206.

14. Chung C.J., Su R.T., Chu H.J., Chen H.T., Tsou H.K., He J.L. Plasma electrolytic oxidation of titanium and improvement in osseointegration. J. Biomed. Mater. Res. B Appl. Biomater, 2013, 101(6), 1023-1030. 